\title{
Comparative Anatomy of Wild Adult African Catfish (Clarias garlepinus) Ovary During Rainy and Dry Peri- ods in Zaria, Nigeria
}

\section{Tauheed Abubakar Muazu*, Mohammed Hadi Sulaiman, Ab- dullahi Baso, Mansur Zubairu, Nura Aliyu Ahmad \& Abubakar Umar Hawwat}

* Department of Veterinary Anatomy, Ahmadu Bello University Zaria, Kaduna State, Nigeria.

With 4 figures and 1 table. $\quad$ Received April, accepted for publication September 2021

\section{Abstract}

The study investigated effects of rainy and dry periods on the ovaries of wild adult Clarias gariepinus in Zaria, kaduna State Nigeria. Twenty-four wild adult catfish with average weight of $1000.00 \pm 0.00 \mathrm{gm}$ was used during both periods. They measured a standard body length of $50.17 \pm 1.01 \mathrm{~cm}$ (rainy) and $44.83 \pm 2.09 \mathrm{~cm}$ (dry). The fish were sourced from Zaria dam and transported live to Gross Anatomy Laboratory in Ahmadu Bello University Zaria. Each fish was euthanized using tricaine anaesthetic at 8 drops/litre of water. The ovaries were extracted, weighed and fixed in Bouin's fluid for 24 hours, and processed histologically. Grossly, the ovaries were observed to be well-developed and highly vascularized during rainy period while, regressed and poorly vascularized ovaries were seen during dry period. The mean weight of the ovaries (0.025) and Gonado-somatic index
(GSI) value (0.034) were significantly higher during rainy period. Histologically, the ovaries were predominated by vitellogenic and post-vitellogenic follicles during rainy period while, previtellgenic follicles predominates dry periods. The tunica albuginea and interstitial connective tissues were thin during rainy period but thick during dry period. Hence, the result of this study revealed that wild adult catfish spawns during rainy period while, dry period is characterized by low gonadal activities in Zaria, Nigeria.

Keywords: Follicles, Gonado-Somatic Index (GSI), Ovary, Wild catfish, Zaria dam.

\section{Introduction}

Catfish (order siluriformes) is a diverse and widespread fresh water group of Ostariophysan fish (Michael, 1996). Catfish is the most diverse fish order and the second or third order among 
vertebrates; it represents 1 in 10 of the fish and 1 in 20 of the vertebrates (Van Dyk and Pieterse, 2008). Fish forms an important source of human diet as they provide proteins, fats, and especially vitamins $A$ and $D$ (Oguntuase and Adebayo, 2014). Special importance of fish is that they contain vitamin B which is not present in plant food (Oguntuase and Adebayo, 2014). The ovaries of African catfish are paired sac-like organs located in the peritoneal cavity into which extend numerous ovigerous folds lined by germi nal epithelium (Anil kumar and kanika, 2017). Like in other teleost, oogonia of C. gariepinus proliferate into primary oocytes which develops within the follicle, formed cortical alveoli, entered vitellogenesis, undergoes maturation, and finally release (ovulation) (Babatunde and Olanike, 2015).

Although, aquaculture activities in $\mathrm{Ni}-$ geria started about 50 years ago (Olagunju et al., 2007), Nigeria has not been able to meet protein requirement of its populace. Thus, the study of the gross and histological variations in the ovary of wild adult Clarias gariepinus during rainy and dry periods will enrich the existing data on the growth and production of African catfish in Nigeria.

\section{Materials and Methods}

\section{Study Area}

The study was carried out in Zaria, Kaduna State of Nigeria. Zaria is located at Latitude 110 4'0" North, 70 42' 0" East (Tanko et al., 2012). Zaria is situated in the northern Guinea Savanna Zone with a tropical continental climate possessing distinct rainy (MayOctober) and dry (November-April) seasons. Zaria has an average annual temperature of $24.9{ }^{\circ} \mathrm{C} / 76.8{ }^{\circ} \mathrm{F}$ and rainfall of $1050 \mathrm{~mm} / 41.3$ inch (Climate office IAR-ABU Zaria, Kaduna-Nigeria). Zaria Dam is located in Zaria city, it was constructed in 1975 on the river Galma to carter for Zaria township water supply and other benefits. The dam has a designed live reservoir capacity of 15.875 million $\mathrm{m} 3$, length of 900 meters and a maximum height of 15 meters from the river bed (Tanko et al., 2012). Zaria dam is located on latitudes $11^{\circ} 07^{\prime} 45^{\prime \prime} \mathrm{E}$ to $11^{\circ} 08^{\prime} 20^{\prime \prime} \mathrm{E}$ and longitudes $07^{\circ} 46^{\prime} \mathrm{N}$ to $07^{\circ} 48^{\prime} \mathrm{N}$ (Tanko et al., 2012).

\section{Experimental animals}

Twenty-four (24) wild adult C. gariepinus were sourced from Zaria Dam, Kaduna State, Nigeria during rainy and dry periods of the year 2017/2018. Twelve each were obtained during rainy period (May-October) and dry period (November-April). The fishes were transported live in open plastic troughs containing clean water to the Gross Anatomy Laboratory in the Department of Veterinary Anatomy, Ahmadu Bello University Zaria.

\section{Morphometric parameters}

The weight and length of each fish was determined using Mettler Toledo balance with sensitivity of $0.01 \mathrm{gm}$ (Vastro India) and measuring tape, respect- 
tively. The weight and dimensions of the ovaries were determined using Mettler Toledo balance with sensitivity of $0.001 \mathrm{gm}$ (Vastro India) and Vernier caliper (model number Y308 Henny), respectively. Photographs were taken using canon digital camera power shot (SX170 IS) with 64-megapixel sensor (focal length: $28-448 \mathrm{~mm}, 7.5 \mathrm{~cm}$ (3.0") TFT.

The Gonado-somatic index was used for following up periodic variations in the gonads weight as related to the body weight of each fish in gram by the formula:

GSI = Gonad weight $/$ Fish body weight $X 100$ (Mahmoud and Badia, 2014).

\section{Harvest of Ovaries}

Each fish was euthanized using tricaine MSS anaesthetic at 8 drops/liter of water (Bowser, 2001). A midventral incision was made between the pectoral fins to about one centimeter to the genital opening (a cylindrical opening situated caudal to the anal opening) and the ovaries were carefully extracted using scalpel blade, pair of scissors and forceps.

\section{Histology}

The extracted ovaries were fixed in Bouin's fluid for 24hour, dehydrated through series of ascending concentrations of ethanol $(70 \%, 90 \%, 100 \%$, $100 \%, 100 \%$ ) for 2 hours at each concentration, cleared in xylene, embedded in paraffin wax and sectioned at $5 \mu \mathrm{m}$. Hematoxylin \& Eosin was used for histological evaluation (Bancroft, 2018).

\section{Data analysis}

All data obtained were expressed as mean \pm standard deviation $(n=24)$. Statistical comparison between rainy and dry periods was made by subjecting the data to independent student ttest using GraphPad Prism version 5.0 for windows. Values of $P<0.05$ was considered significant.

\section{Results}

The average body weight was 1000.00 gm during rainy and dry periods, with a standard body length of $50.17 \pm 1.01$ $\mathrm{cm}$ and $44.83 \pm 2.09 \mathrm{~cm}$ during rainy and dry periods respectively. From (Table 1) The mean weight of the ovaries was significantly higher during rainy period (0.025) compared to dry period. Also, the mean Gonado-somatic index (GSI) value was significantly higher during rainy period (0.034) compare to dry period. Fig (1) shows a well-developed and highly vascularized ovary of $1 \mathrm{~kg}$ catfish during rainy period while Fig (2) shows a regressed and poorly vascularized ovary of $1 \mathrm{~kg}$ catfish during dry period. Fig (3) shows predominantly vitellogenic and post-vitellogenic follicles with thin tunica albuginea and thin interstitial connective tissue during rainy period while, Fig (4) shows predominantly pre-vitellogenic follicles with thick tunica albuginea and thick 
interstitial connective tissue during dry period.

\section{Discussion}

The mean value of length and weight obtained for $C$. gariepinus in this study which was used in determining the maturity of the fish agrees with Babatunde and Olanike, (2015). However, ovarian development in catfish is influenced by several factors which includes environmental factors, hormonal factors and nutrition (Xiao et al., 2014). The ovaries of African catfishes are paired saclike organs located in the peritoneal cavity into which extends numerous ovigerous folds lined by germinal epithelium (Anil kumar and kanika, 2017). Like in other teleost, oogonia of $C$. gariepinus proliferate into primary oocytes which develops within the follicle, formed cortical alveoli, entered vitellogenesis, undergoes maturation, and finally release (ovulation) (Babatunde and Olanike, 2015).

At maturity, ovaries of $C$. gariepinus are composed of oocytes of different size and stages, ranging from synchronous population of large oocytes defined as a clutch, to previtellogenic and vitellogenic smaller oocytes intermingling with mature ova. Each matured ovum is surrounded by zona radiata which makes them conspicuously bigger in size (Babatunde and Olanike, 2015).

The study of the effects of rainy and dry periods on the ovary of a mature wild C. gariepinus has not been documented in Nigeria to the best of our knowledge. Hence, the results obtain from this study would add to the existing literatures on catfish production in Nigeria. Grossly, during the rainy period, the ovaries were well developed and highly vascularized, this is in agreement with the findings of ElZoghby et al. (2008). They reported that the weight, size and diameter of the reproductive organs of Catfish are significantly higher during spawning season. While, during dry period the ovaries were regressed and poorly vascularized, this is in line with the findings of Singh and Joy (1999), who reported that, during non-spawning season, the reproductive organs of Claria batracus including the testis tend to regress and possibly change color.

The mean weight of both ovaries was significantly higher during rainy period (0.025) compare to dry period, this equally agrees with the findings of ElZoghby et al. (2008) who reported that the weight, size and diameter of the reproductive organs of Catfish are significantly higher during spawning period compared to non-spawning period.

The mean GSI value was significantly higher during rainy period (0.034) compare to dry period, this agrees the findings of Mahmoud and Badia (2014), who reported a higher GSI value during the spawning season of Clarias lazera. Histologically, the 
ovaries of C. gariepinus was predominated by vitellogenic and post-vitellogenic follicles during rainy period with thin tunica albuginea and interstitial connective tissue, but during dry period the ovary was predominated by pre-vitellogenic follicles with thick tunica albuginea and thick interstitial connective tissue, this agrees with the findings of Mahmoud and Badia (2014) who reported a similar domination of the ovaries of Clarias lazera by vitellogic and post-vitellogenic follicles during breeding season while pre-vitellogenic follicles predominates nonbreeding season.

\section{Conclusion}

The results obtained in this study revealed that rainy period is the spawning period for wild adult catfish in Zaria, Nigeria, while dry period is characterized by low gonadal activities.

Conflict of interest: No conflict of interest

\section{Ethical Statement}

An ethical approval was given by Animal research committee of Ahmadu Bello University Zaria with an approval number of ABU/CAUC/2020/014.

Funding: The research was funded by the corresponding author

\section{Authors contributions}

All authors contributed substantially to the design, acquisition, and analysis of the study. Writing and revising for intellectual consumption was also collectively done.

\section{References}

Anil kumar, T., \& kanika, P. (2017):

Ovarian development of African sharp tooth catfish Clarias gariepinus from Delhi segment of river Yamuna. J. Fish. Aquat. Sci., 12 (3):117-126.

Babatunde, A.S., \& Olanike, K.A. (2015): Gonadal development in Nigerian female Clarias gariepinus. J. Aquac. Res. Dev.., 6 (6): 341.

Bancroft, J. D., Layton, C. \& Suvarna, K. S. (2018). Bancroft's theory and practice of histological techniques E-book. Elsevier Health Sciences.

Bowser, P. R. (2001): Anesthetic options for fish. In: Recent Advances in Veterinary Anesthesia and Analgesia: Companion Animals, (Gleed RD \& Ludders JW, editors). International Veterinary Information service, Ithaca, New York, pp. 1-3.

El-Zoghby, I.M.A., Bakry, H.H., Ghallab, A.M., \& Emam, M.A. (2008): Histological Studies on the Gonads of the Catfish during Different Seasons. Lucrari stiintifice seria, Medicina Veterinara, 52 (11): 243.

Mahmoud, A.E., \& Badia, A. (2014): Seasonal histological changes in the gonads of catfish, Clarias lazera. Fish. Aquac. J., 5: 087. 
Michael, N. B. (1996): Alternative lifehistory strategies of catfishes. Aquatic living resources, 9 (S1): 35-41.

Oguntuase, B. G. \& Adebayo, O. T. (2014): Sperm quality and reproductive performance of male Clarias gariepinus induced with synthetic hormones (Ovatide and Ovaprim). Int. J. fish. Aquacult., 6 (1): 9-15.

Olagunju, F.I., Adesiyan, I.O., \& Ezekiel, A.A. (2007): Economic viability of catfish production in Oyo State, Nigeria. J. human Ecol., 21 (2): 121-124.

Singh, M.S., \& Joy, K.P. (1999): Annual correlative changes in some biochemical contents of seminal vesicles and testis in catfish Claria batracus London. Zoolog. Sci., 16 (2): 345-356.

Tanko, J.A., Oluwadamisi, E.A., \& Abubakar, I. (2012): Agrochemical Concentration Level in Zaria Dam
Reservoir and Ground Waters in the Environs. J. Environ. Prot., 3 (2): 225232.

Van Dyk, J.C., \& Pieterse, G.M. (2008): A histo-morphological study of the testis of sharp tooth catfish (Clarias gariepinus) as reference for future toxicological assessments. J. Appl. Ichthyol., 24 (4): 415-422.

Xiao, J., Zhong, H., Zhou, Y., Yu, F., Gao, Y., et al. (2014): Identification and characterization of microRNAs in Ovary and Testis of Nile Tilapia (Oreochromis niloticus) by using Solexa Sequencing Technology. PLOS ONE, 9(1): e86821.

\section{Author address:}

Dr. Tauheed Abubakar Muazu abubakartauheed1045@gmail.com*

Table (1): Mean \pm SD values of body weight, length and Ovarian parameters of adult wild African catfish (C. gariepinus) during rainy and dry periods.

\begin{tabular}{llll}
\hline Parameters & \multicolumn{2}{c}{ Mean \pm SD (n=24) } & p-value \\
\hline & Dry Period & Rainy Period & \\
BW $(\mathrm{gm})$ & $1000.00 \pm 0.00$ & $1000.00 \pm 0.00$ & \\
BL $(\mathrm{cm})$ & $44.83 \pm 2.09$ & $50.17 \pm 1.01$ & 0.108 \\
LO $(\mathrm{cm})$ & $16.83 \pm 1.48$ & $21.17 \pm 2.03$ & 0.166 \\
DO $(\mathrm{cm})$ & $4.83 \pm 1.20$ & $7.17 \pm 2.60$ & 0.497 \\
WO $(\mathrm{gm})$ & $43.93 \pm 15.91$ & $138.84 \pm 21.99$ & $0.025^{*}$ \\
GSI & $4.39 \pm 1.59$ & $13.88 \pm 0.37$ & $0.034^{*}$ \\
\hline
\end{tabular}

Key: BW= Body weight, $\mathrm{BL}=$ Body length, $\mathrm{LO}=$ Length of ovaries, $\mathrm{DO}=$ Diameter of ovaries, $\mathrm{WO}=$ Weight of ovaries and GSI= Gonado somatic index

$\mathrm{P}<0.05$ are statistically significant 

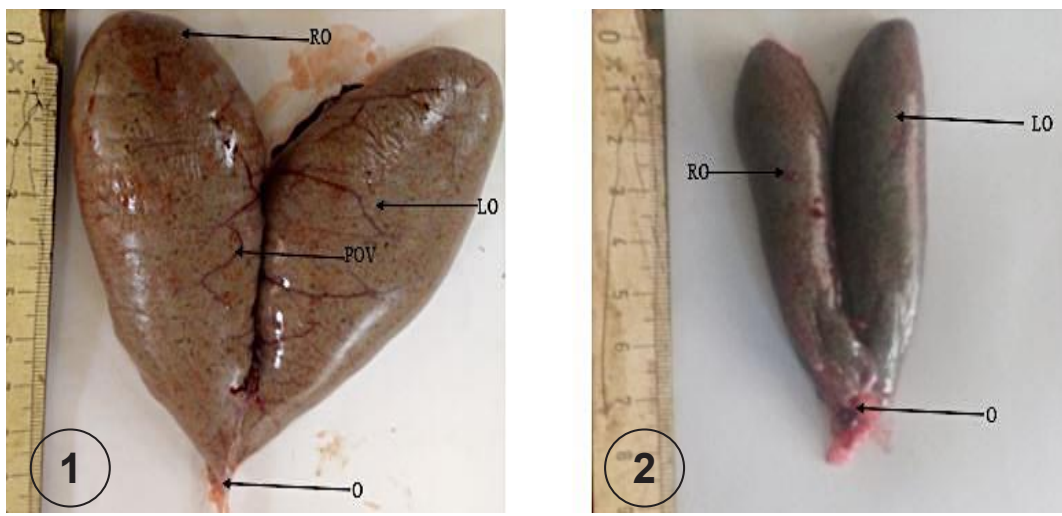

Fig (1): Extracted ovary of a $1 \mathrm{~kg}$ wild Clarias gariepinus during rainy period showing a pair of well-developed and highly vascularized oval shape ovaries with prominent ovarian veins. LO Left ovary, O Oviduct, POV Prominent ovarian veins, RO Right ovary.

Fig (2): Extracted ovary of a $1 \mathrm{~kg}$ wild Clarias gariepinus during dry period showing a pair of Regressed and poorly vascularized ovaries with an oviduct. LO Left ovary, O Oviduct, Ro Right ovary
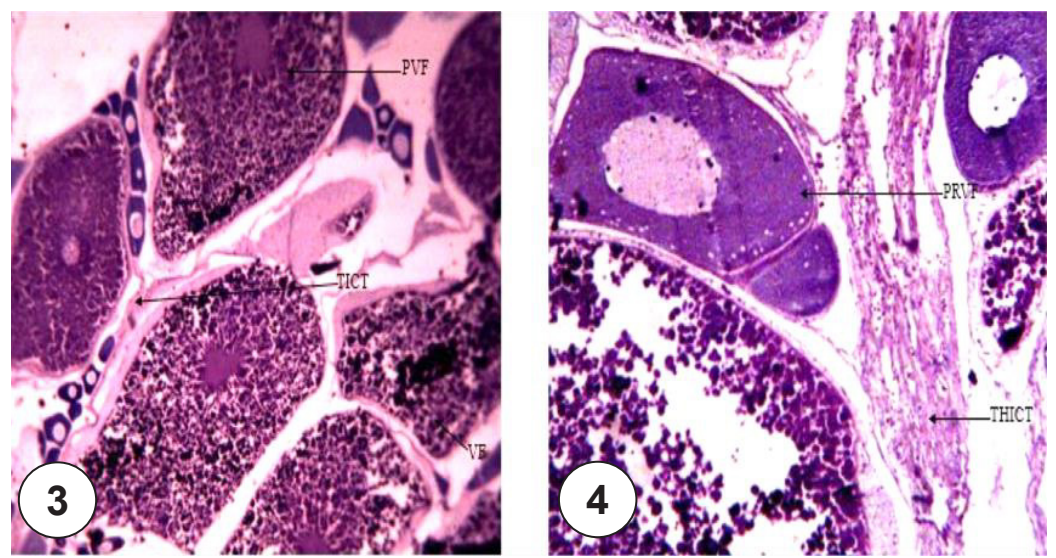

Fig (3): Histological section of the ovary of Clarias gariepinus during rainy period showing vitellogenic and post-vitellogenic follicles with interstitial connective tissue at $5 \mu \mathrm{m}$. H\&E X100. TICT Thin interstitial connective tissue, PVF Post vitellogenic follicle, VF Vitellogenic follicle.

Fig (4): Histological section of the ovary of Clarias gariepinus during dry period showing predominant pre-vitellogenic follicles with thick interstitial connective tissue at $5 \mu \mathrm{m}$. H\&E X100. PRVF pre-vitellogenic follicles, THICT Thick interstitial connective tissue. 


\section{Animal species in this Issue}

\section{Catfish (Clarias gariepinus)}

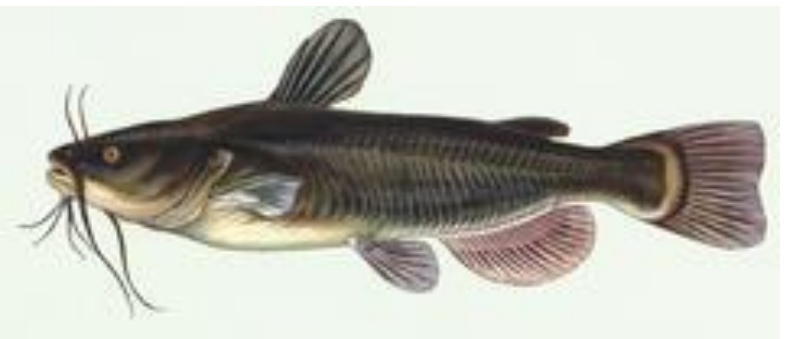

Kingdom: Animalia \& Phylum: Chordata \& Class: Actinopterygii \& Order: Siluriformes \& Family: Clariidae \& Genus: Clarias \& Species: C. gariepinus

Most catfish are bottom feeders. In general, they are negatively buoyant, which means that they will usually sink rather than float due to a reduced gas bladder and a heavy, bony head. Catfish have a variety of body shapes, though most have a cylindrical body with a flattened ventrum to allow for benthic feeding.

A flattened head allows for digging through the substrate as well as perhaps serving as a hydrofoil. Some have a mouth that can expand to a large size and contains no incisiform teeth; catfish generally feed through suction or gulping rather than biting and cutting prey. However, some families, notably Loricariidae and Astroblepidae, have a suckermouth that allows them to fasten themselves to objects in fast-moving water. Catfish also have a maxilla reduced to a support for barbels; this means that they are unable to protrude their mouths as other fish such as carp.

Catfish may have up to four pairs of barbels: nasal, maxillary (on each side of mouth), and two pairs of chin barbels, though pairs of barbels may be absent depending on the species. Catfish barbels always come as pairs. Many larger catfish also have chemoreceptors across their entire bodies, which means they "taste" anything they touch and "smell" any chemicals in the water. "In catfish, gustation plays a primary role in the orientation and location of food". Because their barbels and chemoreception are more important in detecting food, the eyes on catfish are generally small.

Source: Wikipedia, the free encyclopaedia 